\title{
MWCNTs/MoS $\mathbf{M}_{2}$ Decorated Cobalt Oxide Polyhedrons Composite Film Modified Electrode for Electrochemical Determination of Dopamine in Rat Brain and Human Blood Serum Samples
}

\author{
Kogularasu Sakthivel ${ }^{1}$, Mani Govindasamy ${ }^{1}$, Shen-Ming Chen ${ }^{1,}$ *, Akilarasan Muthumariappan ${ }^{1}$, \\ Veerappan Mani ${ }^{1,2}$, Tse-Wei Chen ${ }^{1}$, Shanthi Selvaraj ${ }^{3,4}$ \\ ${ }^{1}$ Department of Chemical Engineering and Biotechnology, National Taipei University of Technology, \\ No.1, Section 3, Chung-Hsiao East Road, Taipei 106, Taiwan \\ ${ }^{2}$ Institute of Biochemical and Biomedical Engineering, National Taipei University of Technology, \\ No.1, Section 3, Chung-Hsiao East Road, Taipei 106, Taiwan \\ ${ }^{3}$ Research Institute of Electronics, Shizuoka University, Japan \\ ${ }^{4}$ Department of Physics and Nanotechnology, SRM University, India \\ *E-mail: smchen78@ms15.hinet.net
}

doi: $10.20964 / 2017.08 .156$

Received: 10 April 2017 / Accepted: 4 June 2017 / Published: 12 July 2017

\begin{abstract}
MWCNTs/MoS 2 decorated Cobalt oxide polyhedrons (MWCNTs/ $\mathrm{MoS}_{2} / \mathrm{Co}_{3} \mathrm{O}_{4} \mathrm{PHs}$ ) were synthesized via facile hydrothermal route. The morphological study clearly revealed the $\mathrm{MWCNTs}_{\mathrm{MoS}}$ decorated on $\mathrm{Co}_{3} \mathrm{O}_{4} \mathrm{PHs}$ and additionally elemental, and electrochemical studies were performed to verify the structure and shape. Owing to excellent synergy between MWCNTs/ $\mathrm{MoS}_{2}$ and $\mathrm{Co}_{3} \mathrm{O}_{4} \mathrm{PHs}$, the composite possesses good porosity, large electrochemical area, roughened surface, and excellent electrocatalytic ability. The development of highly sensitive sensor is essential for dopamine (DA) due to its great significance in physiological, biochemical, pharmaceutical and medicinal applications. A rapid, sensitive, selective, reproducible, and durable electrochemical non-enzymatic DA assay, by employing MWCNTs/ $\mathrm{MoS}_{2} / \mathrm{Co}_{3} \mathrm{O}_{4} \mathrm{PHs}$ modified screen print carbon electrode (SPCE) was described. The sensor displayed outstanding sensitivity with nanomolar limit of detection of $13 \mathrm{nM}$, which is superior to those of previously reported $\mathrm{Co}_{3} \mathrm{O}_{4}$ based electrodes. A rapid, sensitive real-time analysis was demonstrated in rat brain and human blood serum samples.
\end{abstract}

Keywords: $\mathrm{Co}_{3} \mathrm{O}_{4}$ polyhedrons; Molybdenum disulfide; Multiwall Carbon Nanotubes; Analytical Chemistry; Non-enzymatic sensing; Biochemistry.

\section{$\underline{\text { FULL TEXT }}$}


(C) 2017 The Authors. Published by ESG (www.electrochemsci.org). This article is an open access article distributed under the terms and conditions of the Creative Commons Attribution license (http://creativecommons.org/licenses/by/4.0/). 